Revista Destaques Acadêmicos, Lajeado, v. 11, n. 1, 2019. ISSN 2176-3070

DOI: http://dx.doi.org/10.22410/issn.2176-3070.v11i1a2019.1919

http://www.univates.br/revistas

\title{
UTILIZAÇÃO DO MASP (MÉTODO DE ANÁLISE E SOLUÇÃO DE PROBLEMAS) EM UMA GRANJA DE SUÍNOS
}

\author{
Elias Lorenzon ${ }^{1}$, Hélio Diedrich ${ }^{2}$
}

Resumo: As organizações necessitam de constantes melhorias em seus processos, buscando a diminuição das perdas, o aumento de produtividade e, consequentemente, o lucro. Assim sendo, uma Unidade Produtora de Leitões (UPL), em busca destas ações de aprimoramento em seu sistema produtivo, solicitou a realização deste estudo. $\mathrm{O}$ objetivo geral é propor possíveis soluções a um dos problemas que acabam reduzindo a produtividade da empresa, mais especificamente, o problema de esmagamento de leitões no setor de maternidade da UPL Neuton Lorenzon. Quanto aos objetivos específicos, pretende-se: identificar as causas do problema de esmagamento seguido de morte de leitões na UPL; realizar a coleta de dados através de anotações diárias; analisar os dados coletados com o auxílio das ferramentas gerenciais e; apresentar sugestões de melhoria, buscando minimizar o impacto do problema de esmagamento de leitões na UPL. Para atender estes objetivos foi utilizado o MASP (Método de Análise e Solução de Problemas), além de outras técnicas de auxílio como Gráfico de Pareto, Diagrama de Causa e Efeito, PDCA, entre outras ferramentas da qualidade. A coleta de dados foi realizada no local onde ocorre o problema, com o objetivo de observar os detalhes relacionados aos fatores que influenciam o esmagamento de leitões na UPL, contemplando um período de seis meses. No final do artigo é exposto um quadro com propostas de melhorias que podem ser implantadas de acordo com as necessidades e disponibilidade financeira da empresa. O método utilizado neste trabalho se caracteriza como sendo uma pesquisa aplicada, classificada como estudo de caso com abordagem quantitativa e exploratória.

Palavras-chave: Método de Análise e Solução de Problemas. Melhorias. Produtividade. Rentabilidade.

1 Acadêmico do curso de Administração de Empresas da Universidade do Vale do Taquari Univates, Lajeado/RS. E-mail: elias-lorenzon@hotmail.com

2 Bacharel em Administração (FATES), mestre em Engenharia de Produção (UFRGS). Professor de Graduação e Pós-Graduação da Universidade do Vale do Taquari - Univates, Lajeado/RS. E-mail: heliodiedrich@gmail.com 


\section{INTRODUÇÃO}

As empresas do ramo da pecuária sofrem influências dos mercados nacionais e internacionais, sendo que, se torna cada vez mais difícil sua sobrevivência. A oscilação do mercado decorrente da oferta e demanda de produtos, assim como o cenário político-econômico, interferem nos resultados financeiros destas organizações. Além disto, a tecnologia utilizada nos países norte-americanos impõe padrões produtivos que são difíceis de serem alcançados nas propriedades rurais de menor proporção e que não contam com uma estrutura adequada.

Este é o caso da UPL Neuton Lorenzon, uma pequena empresa familiar localizada no interior da cidade de Encantado/RS que atua no ramo da suinocultura a mais de vinte e cinco anos, a qual será analisada neste artigo.

Trabalhando a partir de métodos e processos simplificados, a empresa desempenha suas atividades de maneira que seus resultados estão abaixo dos índices de produtividade apresentados por Ferreira et al. (2014, p. 176), que correspondem a uma taxa de mortalidade pré-desmame de $6 \%$ e 28 leitões desmamados por porca por ano. Assim sendo, será utilizado neste artigo o Método de Análise e Solução de Problemas (MASP), juntamente com ferramentas gerenciais como Diagrama de Causa e Efeito, Gráfico de Pareto e PDCA (do inglês, Plan, Do, Check, Act).

Ferreira et al. (2014, p. 804) entendem que "incorporar as ferramentas gerenciais à gestão da empresa suinícola parece ser o melhor caminho para que o gerenciamento da qualidade total seja efetivamente seguido por todos os colaboradores". Ainda conforme os autores, a gestão pela qualidade total, é uma importante opção para as empresas conquistarem vantagem competitiva perante o mercado produtor e consumidor globalizado (FERREIRA et al., 2014, p. 804).

Em vista a melhorar seus resultados, a empresa UPL Neuton Lorenzon entende que precisa solucionar o problema de alto índice de esmagamento de leitões no setor de maternidade, o qual gera perdas de até $7 \%$ em seu faturamento mensal. Portanto, o objetivo geral do trabalho é propor possíveis soluções ao problema de esmagamento de leitões na UPL, por meio da utilização do MASP. Em relação aos objetivos específicos, pretende-se:

1- Identificar as possíveis causas do problema de esmagamento de leitões na UPL;

2- Realizar a coleta de dados através de anotações diárias;

3- Analisar os dados coletados com o auxílio das ferramentas gerenciais;

4- Apresentar sugestões de melhoria, buscando minimizar o impacto do problema de esmagamento de leitões na UPL.

Os dados apresentados são referentes ao processo produtivo da UPL, visto que não se aplicam a outra organização. Então, as conclusões acerca deste 
estudo podem não ser assertivas se aplicadas a outras empresas do mesmo ramo. Por isto, para obter resultados positivos em outras organizações é indispensável a adaptação deste estudo.

\section{FUNDAMENTAÇÃO TEÓRICA}

Neste capítulo são apresentados conceitos de autores relacionados ao sistema produtivo de suínos, Administração da Produção, MASP (Método de Análise e Solução de Problemas), Coleta de Dados, Diagrama de Pareto, Diagrama de Causa e Efeito, Brainstorming e Plano de Ação 5W 2H. Estas considerações têm como objetivo auxiliar o entendimento a respeito deste artigo.

Conforme Souza et al. (2013), a unidade produtora de leitões, na maior parte da suinocultura brasileira, é especializada na inseminação das fêmeas, gestação, parição e criação dos animais até o desmame ou a saída da creche.

Ainda, segundo Souza et al. (2013, p. 26):

Para uma boa gestão de uma granja, é fundamental, no entender da Embrapa Suínos e Aves, definir as metas de produtividade a serem atingidas e a forma como os dados serão anotados e organizados, dando clareza sobre a obtenção ou não das metas traçadas. [...] Grande parte do sucesso de uma granja de suínos depende da avaliação/acompanhamento de indicadores de produtividade e da obtenção de bons índices produtivos, baseados em dados reais registrados na granja.

Diante disto é importante que haja a administração adequada do sistema produtivo nas empresas. Ritzman e Krajewski (2004) compreendem que administrar a produção e operações refere-se ao controle e direção dos processos que transformam insumos em produtos e serviços. A administração da produção é fundamental para cada área de uma empresa, pois somente a partir de uma administração bem-sucedida de pessoas, capital, informação e materiais, é possível cumprir suas metas. Portanto, conforme um dos princípios citados pelos autores, cada parte de uma empresa possui sua própria identidade, porém está vinculada a produção (RITZMAN; KRAJEWSKI, 2004).

A administração da produção está relacionada com a produção de bens ou serviços de qualquer organização e tem como objetivo, a máxima produtividade a partir da utilização eficiente dos recursos que the são disponibilizados (ALBERTIN; PONTES, 2016). Logo, é oportuno que as empresas avaliem suas condições, buscando aperfeiçoar seu sistema produtivo, com o intuito de aumentar sua rentabilidade e manter seu crescimento no mercado. 
Conforme Chiavenato (2014), a administração da produção usa recursos físicos e materiais da organização, tais como equipamentos, instalações, matéria-prima, prédios, etc. Estes recursos podem estar presentes na indústria, no campo agrícola, no prédio escolar, na loja, enfim, pois são eles que atribuem à empresa a possibilidade de transformá-los em produtos ou serviços. Ainda de acordo com o autor, a administração da produção deve ser planejada para atender a dois objetivos importantes: alcançar a eficiência e a eficácia no processo produtivo. A eficiência diz respeito à utilização apropriada dos recursos da empresa, enquanto a eficácia está relacionada aos objetivos que se pretende alcançar com suas operações (CHIAVENATO, 2014).

Em vista disso, Biagio (2015) afirma que para administrar a produção com eficiência e eficácia é preciso gerenciar os 8 (oito) Ms de maneira a atendêlos plenamente. Os 8 (oito) Ms da produção são um conjunto de recursos de entrada no sistema produtivo. São eles: (1) Método de trabalho; (2) Mão-deobra; (3) Matéria-prima; (4) Meio ambiente, ou, instalações físicas; (5) Máquinas e equipamentos; (6) Moeda, ou, capital financeiro; (7) Medidas de desempenho; (8) Mensagens, ou, informações.

Assim sendo, para tornar a administração da produção mais eficiente e eficaz, buscando manter a qualidade nas empresas, é importante que seja utilizado o Método de Análise e Solução de Problemas, que pode auxiliar no melhor desempenho da organização. Para Moraes, Borges e Sá (2010), o MASP é uma metodologia que auxilia os gestores a avaliar os processos e identificar as causas dos problemas, com o objetivo de encontrar soluções que possam diminuí-los ou eliminá-los.

O MASP, método embasado no PDCA (Plan, Do, Check, Act), é composto de etapas predefinidas destinadas à escolha de um problema, análise de suas causas, definição e planejamento das ações que estabelecem uma solução, verificação do resultado e geração de aprendizado decorrido de sua aplicação (PIRES, 2014).

Na Figura 1, Campos (2004) mostra cada uma das etapas do PDCA, associadas às 8 (oito) etapas do MASP. 
Figura 1 - MASP como PDCA da melhoria

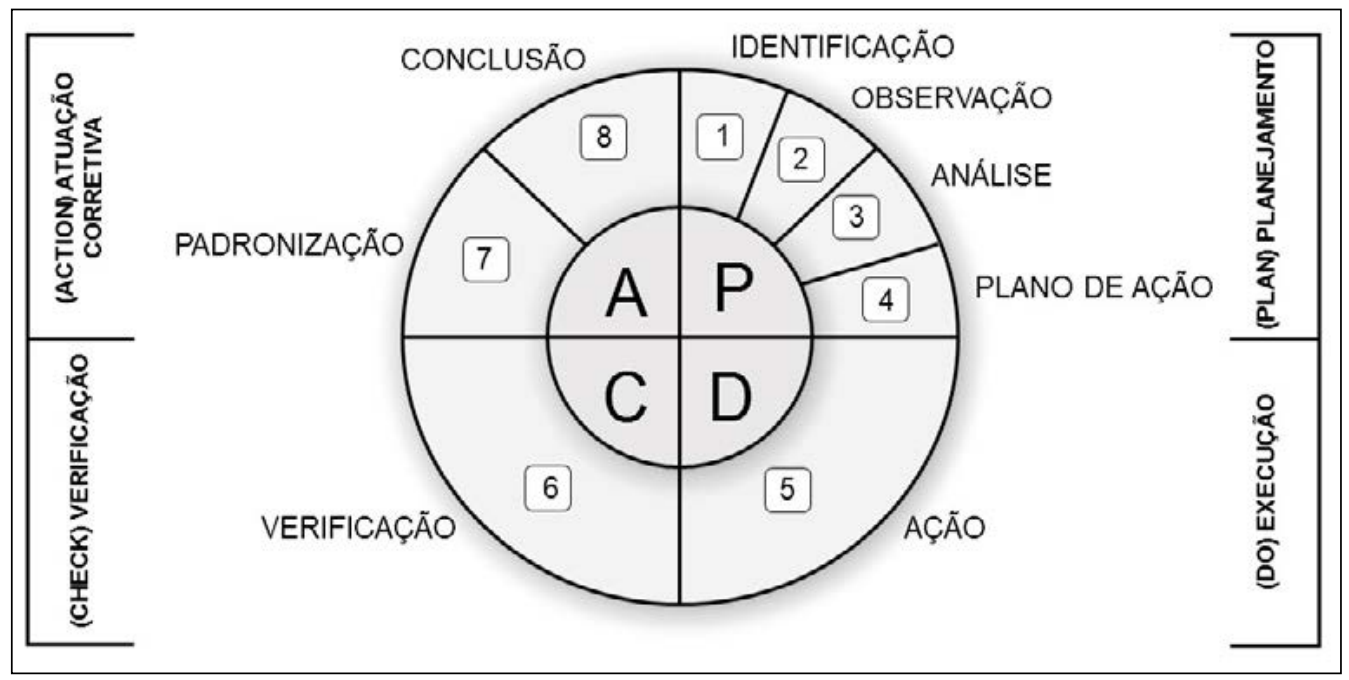

Fonte: Adaptado pelo autor com base em Campos (2004).

Campos (2004) define as etapas do MASP da seguinte forma:

1- Identificação do problema: Na primeira etapa, o problema é definido claramente a partir de uma análise de Pareto, onde são identificadas as perdas e visíveis ganhos atuais, assim como a frequência com que ele vem ocorrendo. Nesta fase também se deve nomear os responsáveis pelo processo.

2- Observação: Esta é a etapa em que são investigadas as características específicas do problema, com uma visão ampla e sob diferentes perspectivas. Através da coleta de dados e observação no local onde ocorre o problema, realiza-se a estratificação por meio de gráficos de Pareto, obtendo assim, os temas mais importantes.

3- Análise: A partir de um Brainstorming, são definidas as principais causas do problema e escolhidas as mais prováveis. Após é realizada uma análise e se confirmadas as causas, ascende-se para a próxima etapa.

4- Plano de ação: Nesta etapa é idealizada uma estratégia de ação com o objetivo de bloquear as causas fundamentais. Porém é preciso certificar-se de que as propostas não causam efeitos colaterais.

5- Ação: A etapa de ação concentra-se em realizar o que foi planejado na fase anterior. No entanto, deve-se apresentar o plano a todos e realizar o treinamento necessário. 
6- Verificação: Nesta etapa são comparados os dados coletados antes e após a ação, podendo assim verificar a continuidade ou não do problema. Se o bloqueio não foi efetivo, retorna-se à etapa da observação.

7- Padronização: A etapa da padronização é destinada a elaboração ou alteração do padrão, com objetivo de prevenir o ressurgimento do problema. Todos precisam ser comunicados e treinados, sendo que deve haver o acompanhamento através de verificações periódicas.

8- Conclusão: Esta é a etapa em que o Método de Solução de Problemas é reavaliado. Identifica-se o que está certo e errado, e mesmo que o processo não tenha ocorrido como planejado, esta etapa pode servir de aprendizado para as próximas aplicações.

Zschornack, Mattioda e Cardoso (2010) concluem que a aplicação do método MASP é de extrema abrangência, pois sua estratégia é capaz de envolver as mais variadas situações empresariais. Ainda conforme os autores, $\mathrm{o}$ método tem uma sistemática estruturada de etapas que permitem diagnosticar problemas e suas possíveis causas e, por conseguinte, traçar alternativas de solução (ZSCHORNACK; MATTIODA; CARDOSO, 2010).

Assim, objetivando identificar todas as possíveis causas de um problema, é importante que se "assegure que a coleta de dados seja feita de modo que os dados representem amostras independentes e em número suficiente para a correta representação do processo" (SANTOS; PEREIRA; OKANO, 2012, p. 6).

Segundo Cervo, Bervian e Da Silva (2007), a coleta de dados é uma importante tarefa da pesquisa que envolve os seguintes passos: a determinação da população a ser estudada; a preparação do instrumento de coleta; o planejamento da coleta e o tipo de dados e de coleta. No entanto, cabe a cada pesquisador decidir qual a melhor maneira de coletar estes dados, tendo em vista a que oferece menos desvantagens e respeitando os objetivos da pesquisa.

Logo, os instrumentos de coleta de dados têm a função de relacionar o que o pesquisador almeja saber com a realidade em que está inserido. Por isso, os dados coletados em uma pesquisa devem, além de fornecer informações significativas, estarem livres de erros sistemáticos, ou seja, serem válidos e precisos (MORON, 1998).

Depois de concluída a coleta de dados, prossegue-se a etapa de análise e discussão, na qual são utilizadas as ferramentas da qualidade. Uma dessas ferramentas é o Gráfico de Pareto, que conforme Barros e Bonafini (2015, p. 50) "[...] oferece melhor visualização da escala de importância de dados".

Seleme e Stadler (2012) entendem que o gráfico permite identificar e classificar os problemas conforme seu grau de importância e ainda indica quais deles precisam ser corrigidos em primeiro lugar.

Para desenvolver um Diagrama de Pareto é necessário organizar os dados de forma que os fatores, ou causas, sejam divididos em essenciais 
e secundários. O gráfico é composto de barras verticais que apresentam a classificação do problema e permitem a definição das prioridades (BARROS; BONAFINI, 2015).

Gozzi (2015) defende que a elaboração do gráfico envolve as seguintes etapas: (1) A definição do problema e em seguida a coleta de dados, onde devem ser registrados o número de observações de cada categoria e o total de observações; (2) Elaboração de uma planilha com os dados distribuídos em colunas referentes às quantidades, categorias, totais acumulados, porcentagens do total e porcentagem acumulada, e; (3) Impressão do gráfico de barras com os valores na ordem decrescente da esquerda para a direita, traçando a curva de valores acumulados.

Na Figura 2, Campos (2004) apresenta um modelo do gráfico de Pareto.

Figura 2 - Exemplo de Diagrama de Pareto

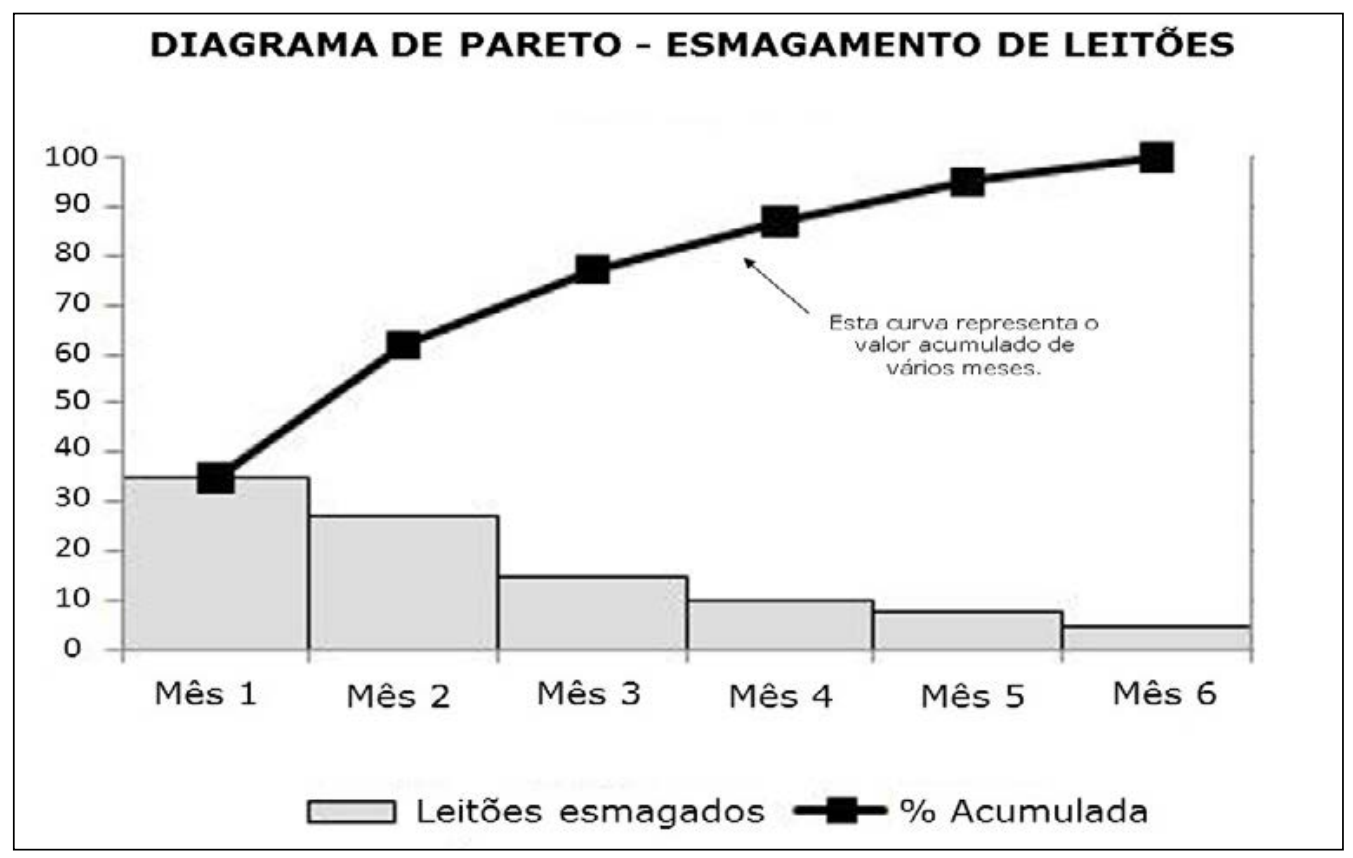

Fonte: Adaptado pelo autor com base em Campos (2004).

A partir da utilização do Gráfico de Pareto, o processo decisório se torna mais rápido, pois ele apresenta os dados de forma mais objetiva, dispensando assim a necessidade de grandes análises (BARROS; BONAFINI, 2015).

Outra ferramenta da qualidade usada durante a aplicação do Método de Análise e Solução de Problemas é o Diagrama de Ishikawa, também conhecido como Diagrama de Causa e Efeito ou Espinha de Peixe (por causa de seu formato). 
“O Diagrama de Causa e Efeito é uma representação gráfica que permite a organização das informações, possibilitando a identificação das possíveis causas de um determinado problema ou efeito" (BOND; BUSSE; PUSTILNICK apud OLIVEIRA, 1996, p. 29).

Barros e Bonafini (2015) complementam que o diagrama é utilizado para identificar a relação entre causas e efeitos de um processo com o objetivo de detectar e analisar os chamados 6 (seis) Ms. São eles: (1) Materiais, (2) Mão de obra, (3) Método, (4) Máquina, (5) Medida e (6) Meio Ambiente. Estes Ms são colocados nas extremidades de cada linha, mas nem sempre há a necessidade de análise de todos eles, isto dependerá das características de cada processo.

Os 6 (seis) Ms devem ser desenhados na espinha do diagrama e à direita escrito o problema. Após listam-se as causas específicas que dizem respeito às variações ocorrentes em um processo (SILVA, A.; SILVA, R., 2017). Na Figura 3, Seleme e Stadler (2012) expõe de forma simplificada a estrutura de um Diagrama de Ishikawa.

Figura 3 - Diagrama de Ishikawa

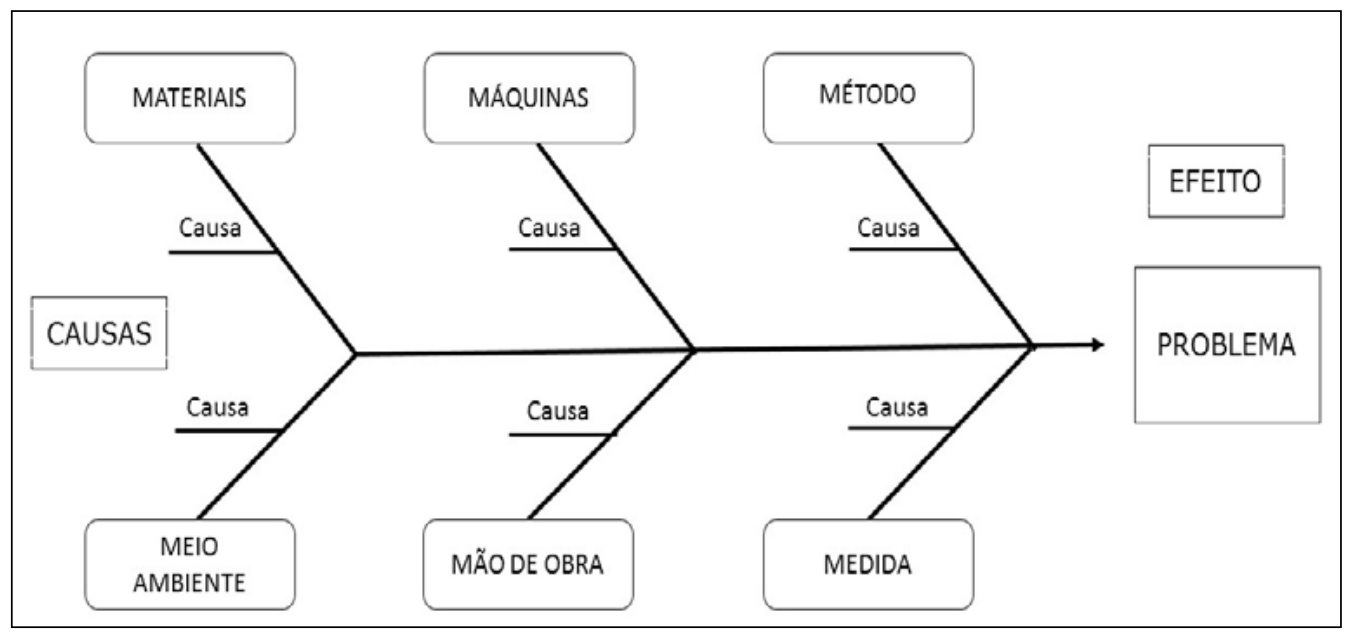

Fonte: Adaptado pelo autor com base em Seleme e Stadler (2012).

Em relação ao Diagrama de Ishikawa, Mello (2010, p. 88) afirma:

Construí-lo é relativamente fácil, e o ideal é que seja feito de maneira coletiva, pelas pessoas que participam do processo. Assim, garantese que nenhuma causa escape à análise, mesmo que são apenas hipóteses. A grande vantagem do diagrama é dar possibilidade de desdobramento e ramificação das causas até chegar àquela que é, efetivamente, a origem do problema. 
Assim, para identificar as causas do problema com mais chances de assertividade, pode-se utilizar a técnica de Brainstorming, que em português significa "tempestade de ideias". Para Bond, Busse e Pustilnick (2012), esta técnica proporciona aos funcionários a participação de maneira ativa na organização, colaborando com sugestões de solução ou melhoria de determinado assunto.

Segundo Arioli (1998, p. 108), "essa técnica é indispensável à geração de novas ideias e conceitos, em qualquer etapa do MASP, particularmente em sua visão holística". O autor ainda complementa que o Brainstorming explora a percepção das pessoas que participam deste trabalho coletivo, potencializando sua eficiência através da cooperação (ARIOLI, 1998).

Conforme Custodio (2015) é preciso que haja uma sequência lógica nas reuniões de Brainstorming para que as etapas tragam resultados positivos à organização. Na sua abordagem, o autor desenvolve a realização da técnica a partir de cinco etapas: (1) Definição da equipe; (2) Introdução do tema; (3) Geração de ideias; (4) Análise e seleção das ideias, e; (5) Priorização das ideias.

Diante disto pode-se dizer que essa ferramenta é considerada de fácil aplicação e ainda desperta a criatividade, inovação e participação dos colaboradores. Porém, deve-se tomar cuidado para não perder o foco e tornar a conversa um simples debate. (BOND; BUSSE; PUSTILNICK, 2012).

Deste modo é concluída a fase de análise do processo. As causas do problema já estarão estabelecidas e com base nisso, será desenvolvido o Plano de Ação (AGUIAR, 2002).

O Plano de Ação 5W 2H segundo Gozzi (2015, p. 98), "[...] é uma ferramenta utilizada para estabelecer um cronograma de planejamento, execução ou monitoramento de trabalhos ou projetos". Ainda conforme o autor, seu nome deriva de 7 (sete) palavras em inglês, sendo cinco com as iniciais "W" (What, Who, When, Where e Why), e duas com as iniciais " $\mathrm{H}$ " (How e How much) (GOZZI, 2015).

No Quadro 1, Silva A. e Silva R. (2017) apresentam um exemplo de Plano de Ação 5W 2H e o que cada letra representa. 
Quadro 1 - Exemplo de Plano de Ação 5W 2H

\begin{tabular}{|c|c|c|c|c|c|c|c|}
\hline \multirow{3}{*}{ Número } & What & What & When & Where & Why & How & How much \\
\cline { 2 - 8 } & O Quê & Quem & Quando & Onde & Por quê & Como & $\begin{array}{c}\text { Quanto } \\
\text { Custa }\end{array}$ \\
\hline 1 & & & & & & & \\
\hline 2 & & & & & & & \\
\hline 3 & & & & & & & \\
\hline 4 & & & & & & & \\
\hline 5 & & & & & & & \\
\hline
\end{tabular}

Fonte: Adaptado pelo autor com base em Silva e Silva (2017).

Silva A. e Silva R. (2017) concluem, portanto, que a partir do uso desta ferramenta, consegue-se apresentar o problema de maneira clara, organizando as etapas que auxiliam na conclusão das soluções mais precisas.

Cabe ressaltar ainda que, além das ferramentas descritas, outras também são importantes e podem ser utilizadas na aplicação do método MASP. Porém, como não serão aplicadas a este estudo, torna-se irrelevante sua referência.

\section{METODOLOGIA DA PESQUISA}

O método de pesquisa conforme Cruz (2009, p. 82), “[...] pode ser definido como um conjunto de dados e regras que permite atingir os objetivos da pesquisa". Assim, este capítulo apresenta a metodologia utilizada, visando fornecer uma ordem para o desenvolvimento do trabalho.

Quanto ao tipo de pesquisa, ela define-se como aplicada, pois o investigador tem a necessidade de contribuir para fins práticos, que podem ser urgentes ou não. Por isso, seu objetivo é solucionar problemas concretos, transformando os resultados de seu trabalho em ações de melhoria (CRUZ, 2009).

Sua classificação pode ser definida como estudo de caso, que segundo Pátaro e Oliva (2017), caracteriza-se pela concentração do pesquisador em um caso específico referente ao tema da pesquisa. Não é um caso qualquer escolhido aleatoriamente, mas sim um caso que possa ser suscetível a análises e comparado com outros similares.

Sua abordagem é considerada quantitativa, pois os dados serão coletados na forma de números e analisados a partir de técnicas estatísticas. Como o tema da pesquisa é pouco estudado, caracteriza-se também como exploratória, sendo necessário um levantamento mais aprofundado do assunto, a fim de trazer mais informações para a elaboração da pesquisa (CRUZ, 2009). 


\section{ANÁLISE E SOLUÇÃO DO PROBLEMA}

Neste capítulo é abordado o problema de pesquisa, com o objetivo de buscar identificar as causas da morte de leitões no setor de maternidade da UPL Neuton Lorenzon e propor possíveis soluções através da aplicação do método MASP (Método de Análise e Solução de Problema).

Para tal, utilizaram-se os quatro primeiros passos do Método, que incluem: (1) a Identificação do Problema, (2) Observação, (3) Análise, e (4) Plano de Ação. Os demais passos que fazem parte do MASP não foram desenvolvidos, pois o período de tempo não foi suficiente para a sua execução. De qualquer forma, o estudo será de grande valia para atingir os objetivos propostos.

Para desenvolver o Método, este estudo teve como objeto uma empresa familiar de pequeno porte vinculada ao setor suinícola, que trabalha com a criação de leitões destinados a fase de creche. A granja está localizada no interior da cidade de Encantado, estado do Rio Grande do Sul.

O processo tem início com a chegada das leitoas gestantes, ou na inseminação das matrizes desmamadas. Estas fêmeas permanecem no "setor da gestação" até o $105^{\circ}$ dia de gestação, quando são deslocadas ao setor da maternidade. Ao completarem, aproximadamente, 114 dias de gestação, acontece o nascimento dos leitões, que permanecem em aleitamento, em média 21 dias, idade na qual o leitão já atinge o peso suficiente para desmame e alojamento na creche.

Em vista disto, é importante destacar que o problema analisado neste estudo, acontece exclusivamente entre o período de nascimento e desmame dos leitões no setor de maternidade da UPL. Na Figura 4 é exposto o problema.

Figura 4 - Leitão esmagado

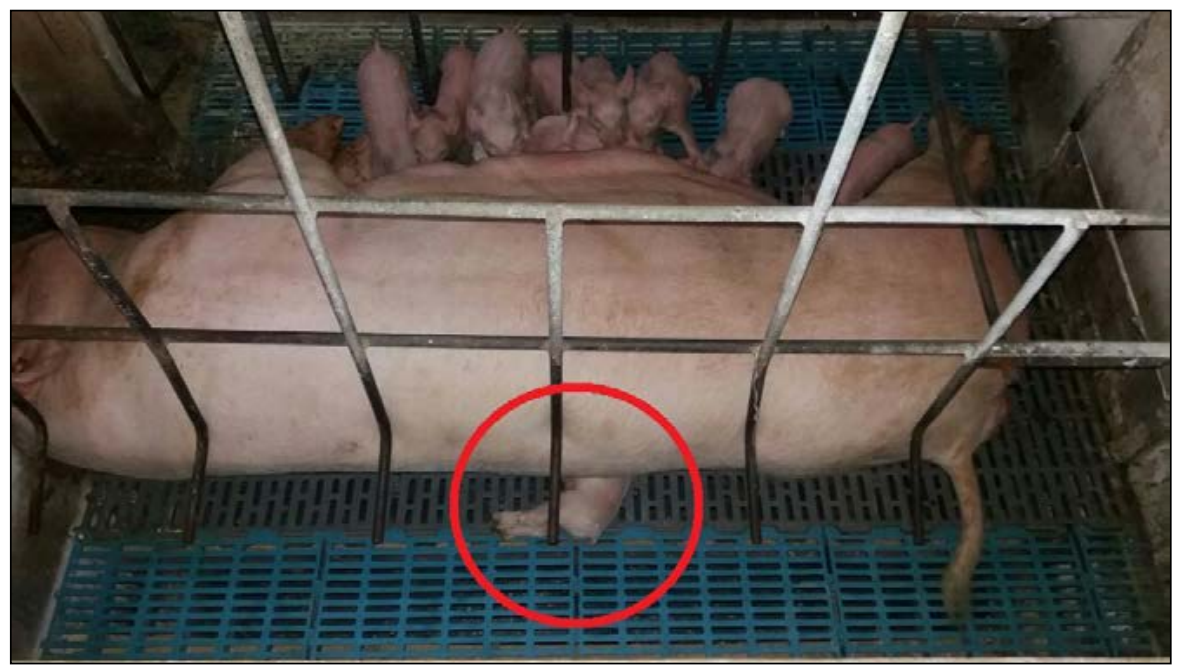

Fonte: Do autor (2018). 
A seguir, é apresentado um levantamento histórico de dados, com o objetivo de explorar o problema e estabelecer suas principais características. Os dados expostos no Gráfico 1 são referentes a frequência mensal com que o esmagamento ocorreu, durante o período de setembro/2017 à fevereiro/2018, onde nasceram no setor da maternidade 4.370 leitões.

Gráfico 1 - Histórico do problema de esmagamento de leitões (Frequência em $\mathrm{n}^{\circ}$ absoluto)

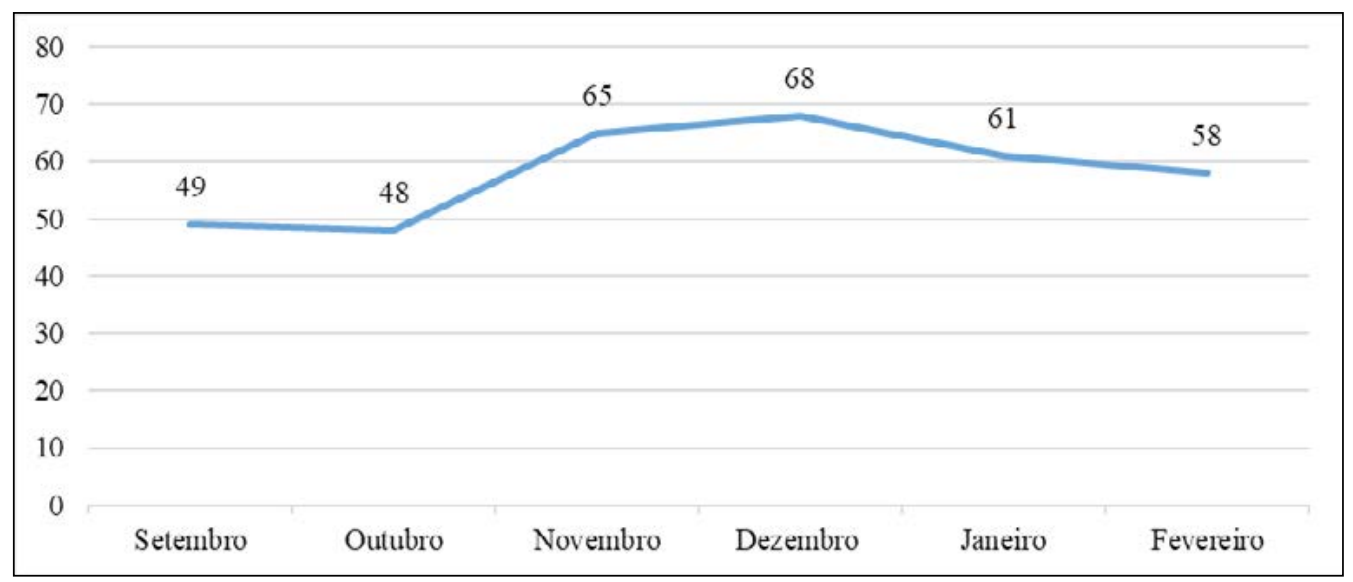

Fonte: Do autor (2018).

Considerando a meta definida por Ferreira et al. (2014, p. 176), que apresenta uma taxa de mortalidade total pré-desmame de $6 \%$, (que inclui mortes por esmagamento, inanição, hipoglicemia, hipotermia, entre outras); observa-se no Gráfico 1, que apenas o esmagamento representa 7,99\% dessas perdas, justificando a utilização do MASP na abordagem deste problema.

Logo, com base no estudo de Abrahão et al. (2004), que expõe uma taxa de mortalidade por esmagamento de $2,61 \%$ do total de leitões nascidos vivos, o Quadro 2 demostra os prejuízos financeiros que o problema representa para a UPL. 
Quadro 2 - Perdas devido à taxa de esmagamento

\begin{tabular}{|l|c|c|c|}
\hline \multicolumn{1}{|c|}{ Mês } & Perdas (R\$) & Meta de 2,61\% (R\$) & Ganhos viáveis (R\$) \\
\hline Setembro & $\mathrm{R} \$ 3.823,20$ & $\mathrm{R} \$ 1.622,53$ & $\mathrm{R} \$ 2.200,67$ \\
Outubro & $\mathrm{R} \$ 3.745,44$ & $\mathrm{R} \$ 1.394,52$ & $\mathrm{R} \$ 2.350,92$ \\
Novembro & $\mathrm{R} \$ 5.071,32$ & $\mathrm{R} \$ 1.675,46$ & $\mathrm{R} \$ 3.395,86$ \\
Dezembro & $\mathrm{R} \$ 5.305,02$ & $\mathrm{R} \$ 1.571,63$ & $\mathrm{R} \$ 3.733,39$ \\
Janeiro & $\mathrm{R} \$ 4.755,72$ & $\mathrm{R} \$ 1.388,41$ & $\mathrm{R} \$ 3.367,31$ \\
Fevereiro & $\mathrm{R} \$ 4.522,74$ & $\mathrm{R} \$ 1.243,87$ & $\mathrm{R} \$ 3.278,87$ \\
\hline \multicolumn{1}{|c|}{ TOTAL } & $\mathrm{R} \$ 27.223,44$ & $\mathrm{R} \$ 8.896,42$ & $\mathrm{R} \$ 18.327,02$ \\
\hline
\end{tabular}

Fonte: Do autor (2018).

Conforme o Quadro 2, o ganho estimado para o período de seis meses é de $R \$ 18.327,02$, o que corresponde a uma redução de $67,32 \%$ nas perdas financeiras por esmagamento de leitões.

Para seguir a aplicação do método MASP, foi essencial a participação de pessoas com conhecimento técnico e do dia a dia das atividades da empresa. Foram convidados a participar, o técnico veterinário responsável pela UPL, a família que trabalha na granja, um comerciante de medicamentos com experiência na atividade, quatro produtores de leitões e um médico veterinário. Assim, encerra-se o primeiro passo do MASP, que é a identificação do problema.

O segundo passo do Método, propõe a observação das características do problema através da estratificação dos dados coletados, sob vários pontos de vista (CAMPOS, 2004).

O Gráfico 2 mostra que o problema de esmagamento de leitões ocorreu de maneira mais expressiva no mês de dezembro de 2017 com 68 casos, o que representa 19,48\% do total apurado no período de 6 meses. Posteriormente, aparecem os meses de novembro com 65 ocorrências, janeiro com 61, fevereiro com 58 , seguidos dos meses de setembro com 49 e outubro com 48 ocorrências. 
Gráfico 2 - Problema de esmagamento de leitões (Frequência em $n^{\circ}$ absoluto)

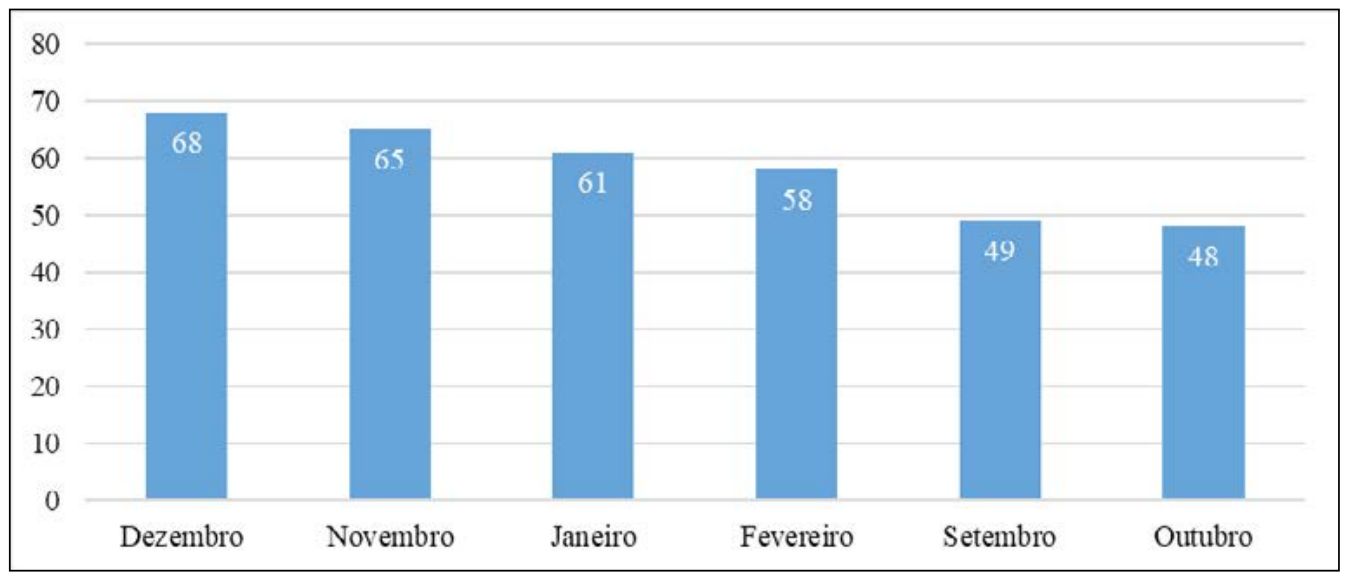

Fonte: Do autor (2018).

Outra variável analisada para a caracterização do problema foi o retrocesso da mortalidade por esmagamento conforme o aumento de idade dos leitões. Observando o Gráfico 3 nota-se que as maiores taxas aconteceram durante os sete primeiros dias de vida do leitão.

Gráfico 3 - Mortalidade por idade do leitão

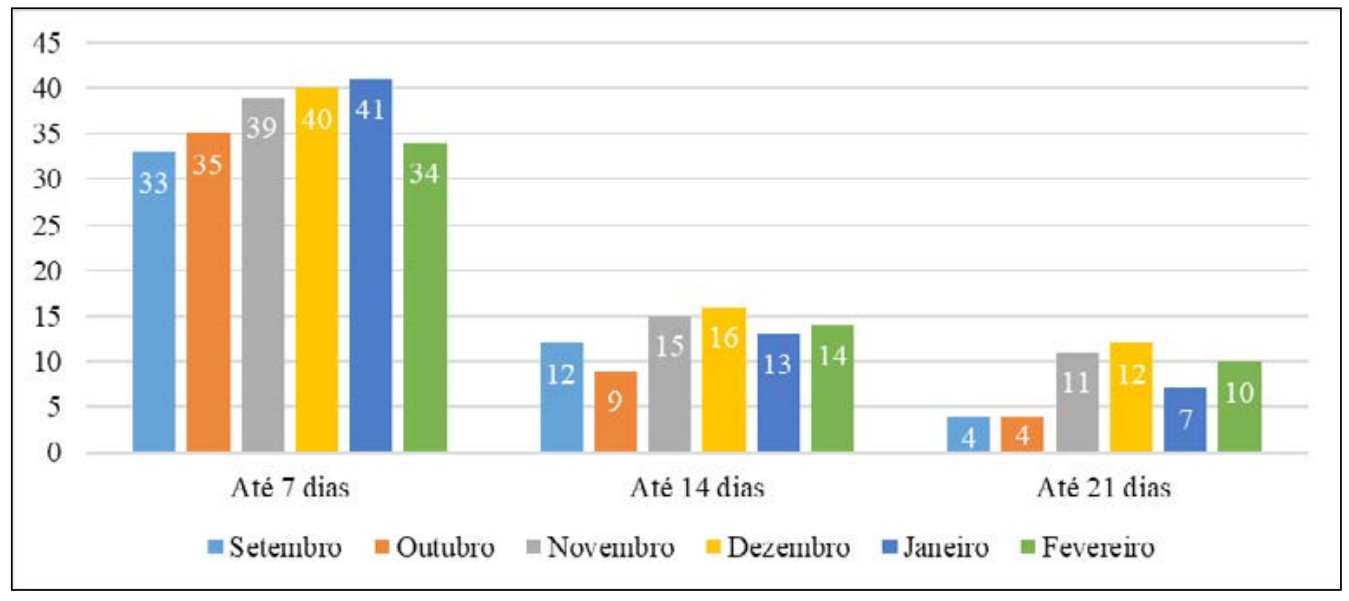

Fonte: Do autor (2018). 
Isto pode ser explicado pelo fato de que os leitões com baixo peso ao nascimento e os últimos a nascerem, ficam excluídos do acesso aos tetos nas primeiras horas de vida, o que impossibilita a ingestão das imunoglobulinas presentes no leite colostro. Assim o leitão fica sem imunidade contra os micro-organismos patogênicos do ambiente, e, portanto, mais suscetível ao esmagamento (FERREIRA ET AL., 2014).

Constatou-se também que, a posição da cela onde mais ocorre o esmagamento é na parte de traz, representando $48 \%$ do total de leitões analisados. Contudo, é importante afirmar que a UPL dispõe de dois tipos de portas de contenção traseira, uma antiga e outra moderna. A maior frequência ocorreu na que possui a tecnologia mais antiga.

Observou-se ainda, que as matrizes de maior tamanho esmagam mais leitões, principalmente no turno da noite, quando ninguém permanece na granja. Os leitões alocados nas celas que não possuem o equipamento amortecedor também tiveram maior índice de mortalidade por esmagamentos, assim como, os lotes que não utilizam o escamoteador como abrigo.

Continuando a aplicação do MASP, o terceiro passo objetiva definir as causas influentes, e escolha das causas mais prováveis do problema.

Para isso, foi utilizada a ferramenta de Brainstorming em paralelo com o Diagrama de Causa e Efeito. Foi convidado a participar da troca de ideias e elaboração do diagrama, o técnico veterinário responsável pela UPL, a família que trabalha na granja, o comerciante de medicamentos com experiência na atividade, os quatro produtores de leitões e o médico veterinário.

Como apresentado na Figura 5, as causas foram separadas em Materiais, Máquinas, Método, Meio Ambiente, Mão de Obra e Medida. 
Figura 5 - Aplicação do Diagrama de Causa e Efeito

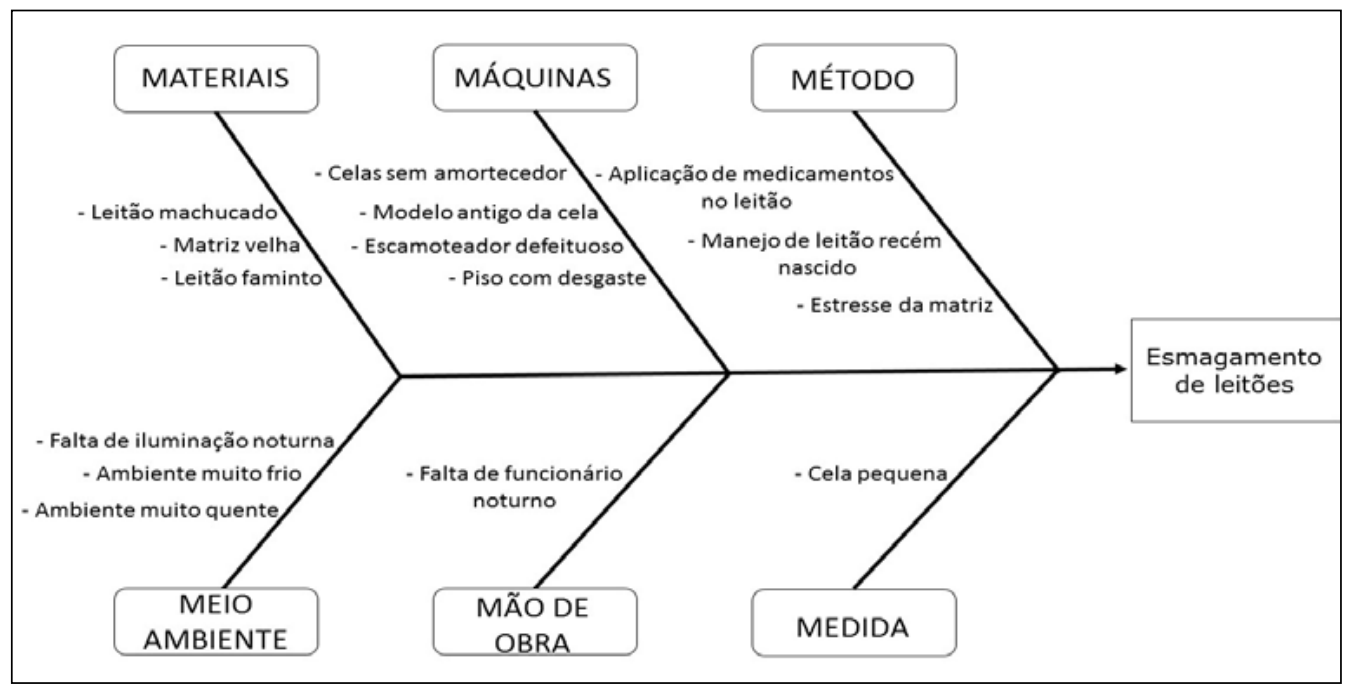

Fonte: Do autor (2018).

Após a definição das causas influentes, apresentadas no Diagrama de Causa e Efeito, realizou-se a análise das causas prováveis e pouco prováveis, a fim de direcionar os esforços na solução do problema. Esta separação das causas mais prováveis, foi elaborada em conversa com o mesmo grupo de pessoas que participou da discussão das possíveis causas do problema, como mostra o Quadro 3.

Quadro 3 - Separação das causas do problema de esmagamento de leitões

\begin{tabular}{|l|l|l|}
\hline \multicolumn{1}{|c|}{ Causa } & Hipótese & \multicolumn{1}{c|}{ Justificativa } \\
\hline Matriz velha & Provável & $\begin{array}{l}\text { A matriz com maior idade tende a ter menos cuidado ao } \\
\text { deitar-se; seu tamanho é maior. }\end{array}$ \\
\hline Leitão machucado & $\begin{array}{l}\text { Pouco } \\
\text { provável }\end{array}$ & $\begin{array}{l}\text { Leitões machucados tendem a ficar pelos cantos da cela ou no } \\
\text { escamoteador, reduzindo as chances de esmagamento. }\end{array}$ \\
\hline Leitão faminto & Provável & $\begin{array}{l}\text { Leitões famintos ficam embaixo da matriz a procura de } \\
\text { alimento (leite). }\end{array}$ \\
\hline Piso com desgaste & Provável & $\begin{array}{l}\text { Alguns pisos de ferro apresentam fissuras onde os leitões } \\
\text { podem ficar trancados pelas patas. }\end{array}$ \\
\hline $\begin{array}{l}\text { Celas sem } \\
\text { amortecedor }\end{array}$ & Provável & $\begin{array}{l}\text { 80\% das celas não possui o equipamento amortecedor, o qual } \\
\text { é utilizado a fim de evitar o esmagamento. }\end{array}$ \\
\hline $\begin{array}{l}\text { Modelo antigo de } \\
\text { cela }\end{array}$ & $\begin{array}{l}\text { Pouco } \\
\text { provável }\end{array}$ & $\begin{array}{l}\text { Outros produtores relataram possuir o mesmo tipo de cela, } \\
\text { porém não tem alto índice de esmagamento de leitões. }\end{array}$ \\
\hline $\begin{array}{l}\text { Manejo de leitão } \\
\text { recém-nascido }\end{array}$ & Provável & $\begin{array}{l}\text { O manejo ou classificação dos leitões recém-nascidos causa em } \\
\text { muitos casos o estresse da matriz. Isso faz com que ela levante } \\
\text { e deite muitas vezes, aumentando as chances de esmagamento } \\
\text { dos leitões. }\end{array}$ \\
\hline
\end{tabular}




\begin{tabular}{|c|c|c|}
\hline Causa & Hipótese & Justificativa \\
\hline $\begin{array}{l}\text { Escamoteador } \\
\text { defeituoso }\end{array}$ & \begin{tabular}{|l|} 
Pouco \\
Provável \\
\end{tabular} & $\begin{array}{l}\text { Os escamoteadores são testados antes do alojamento das } \\
\text { matrizes na sala de maternidade. }\end{array}$ \\
\hline Estresse da matriz & Provável & $\begin{array}{l}\text { A matriz mais estressada tende a levantar e deitar muitas } \\
\text { vezes durante o dia. }\end{array}$ \\
\hline $\begin{array}{l}\text { Aplicação de } \\
\text { medicamentos no } \\
\text { leitão }\end{array}$ & $\begin{array}{l}\text { Pouco } \\
\text { provável }\end{array}$ & $\begin{array}{l}\text { É uma prática comum entre produtores, que não causa } \\
\text { nenhum malefício ao leitão. }\end{array}$ \\
\hline $\begin{array}{l}\text { Falta de } \\
\text { iluminação } \\
\text { noturna }\end{array}$ & Provável & $\begin{array}{l}\text { Os leitões em aleitamento ficam no escuro durante a noite, } \\
\text { impossibilitando a visão para possível fuga quando a matriz } \\
\text { deita. }\end{array}$ \\
\hline $\begin{array}{l}\text { Ambiente muito } \\
\text { frio }\end{array}$ & Provável & $\begin{array}{l}\text { Os leitões tendem a deitar-se embaixo da matriz, pelo fato do } \\
\text { piso ficar quente quando ela levanta-se. }\end{array}$ \\
\hline $\begin{array}{l}\text { Ambiente muito } \\
\text { quente }\end{array}$ & Provável & $\begin{array}{l}\text { Aumenta o nível de estresse das matrizes fazendo com que } \\
\text { elas se joguem ao deitar; os leitões tendem a ficar fora do } \\
\text { escamoteados em busca de um ambiente mais agradável e } \\
\text { ventilado. }\end{array}$ \\
\hline $\begin{array}{l}\text { Falta de } \\
\text { funcionário } \\
\text { noturno }\end{array}$ & Provável & $\begin{array}{l}\text { Sem a presença do funcionário noturno, fica impossível evitar } \\
\text { uma morte por esmagamento durante a noite. }\end{array}$ \\
\hline Cela pequena & $\begin{array}{l}\text { Pouco } \\
\text { provável }\end{array}$ & $\begin{array}{l}\text { As celas têm as dimensões de acordo com os padrões } \\
\text { estabelecidos pelo cliente, com base em estudos anteriormente } \\
\text { realizados. }\end{array}$ \\
\hline
\end{tabular}

Fonte: Do autor (2018).

\section{MASP.}

Assim, encerra-se a Análise do Problema, que é o terceiro passo do

Em sequência, com o objetivo de minimizar impacto do problema de esmagamento de leitões, é apresentada uma proposta com sugestões de melhoria que podem ser implantadas na UPL. O Quadro 4 expõe estas propostas.

Quadro 4 - Descrição dos problemas encontrados e sugestões de melhorias

\begin{tabular}{|l|c|l|}
\hline $\mathbf{N}^{\circ}$ & $\begin{array}{c}\text { Problemas } \\
\text { identificados }\end{array}$ & \multicolumn{1}{c|}{ Sugestões } \\
\hline 1. & $\begin{array}{l}\text { Falta de controle } \\
\text { sobre o problema }\end{array}$ & $\begin{array}{l}\text { Desenvolver uma planilha em Excel para controle e histórico de esmagamento } \\
\text { de leitões. Ela deve estar disponível no computador da granja e com fácil } \\
\text { acesso a todos os trabalhadores. Neste documento devem conter o código da } \\
\text { matriz, a quantidade de leitões esmagados por parto e seu nível de estresse } \\
\text { ao receber leitões de outras fêmeas. Isso servirá como base para analisar a } \\
\text { viabilidade dela continuar na granja ou ser descartada. Este documento deve } \\
\text { ser providenciado com a maior brevidade possível. }\end{array}$ \\
\hline
\end{tabular}




\begin{tabular}{|c|c|c|}
\hline $\mathbf{N}^{\circ}$ & $\begin{array}{c}\text { Problemas } \\
\text { identificados }\end{array}$ & Sugestões \\
\hline 2. & $\begin{array}{l}\text { Matriz velha e de } \\
\text { tamanho grande }\end{array}$ & $\begin{array}{l}\text { Controlar a alimentação das matrizes com maior rigidez a fim de reduzir seu } \\
\text { tamanho. Para isso, os trabalhadores da granja precisam pesar a quantidade } \\
\text { de ração a ser oferecida aos animais com o auxílio de uma balança, que } \\
\text { deverá estar disponível nos galpões da gestação e da maternidade. A } \\
\text { quantidade correta de ração deve ter como base o padrão estabelecido pelo } \\
\text { cliente/parceiro da UPL. Estes padrões devem estar descritos em uma tabela } \\
\text { localizada no mural do escritório, com fácil acesso a todos que realizam o } \\
\text { arraçoamento dos animais. Também, deve-se analisar o histórico de idade } \\
\text { da matriz e o número de leitões desmamados; que estará disponível no } \\
\text { computador da granja. Se forem comprovadas perdas significativas por } \\
\text { esmagamento, ou idade avançada da matriz, ela deve ser descartada. Essas } \\
\text { ações podem ser implementadas imediatamente. }\end{array}$ \\
\hline 3. & Leitões famintos & $\begin{array}{l}\text { Disponibilizar ração aos leitões, para que suas necessidades alimentares } \\
\text { sejam completadas. Devem ser instalados coxos auxiliares a partir do } 10^{\circ} \text { dia } \\
\text { de aleitamento na parte de traz de todas as celas com leitões. Estes coxos } \\
\text { devem ser reabastecidos com ração diariamente. Se forem constatadas fezes } \\
\text { na parte interna, estes coxos devem ser lavados com água, posteriormente } \\
\text { desinfetados e reabastecidos. Se no dia seguinte os leitôes continuarem } \\
\text { defecando no coxo, ele pode ser realocado dentro da cela. É preciso definir } \\
\text { um responsável para esta atividade, porém todos os trabalhadores da granja } \\
\text { precisam ter conhecimento para eventual falta do responsável. Estes coxos } \\
\text { podem ser instalados imediatamente, ou de acordo com a disponibilidade } \\
\text { financeira para aquisição dos equipamentos. }\end{array}$ \\
\hline 4. & $\begin{array}{l}\text { Piso de ferro com } \\
\text { desgaste }\end{array}$ & $\begin{array}{l}\text { Substituir os pisos de ferro defeituosos por novos, ou concertá-los, para que } \\
\text { não haja fissuras maiores que } 1 \mathrm{~cm} \text {, onde os leitões podem ficar trancados. } \\
\text { Em caso de substituição, estes pisos podem ser de plástico ou ferro, conforme } \\
\text { melhor se adapta a estrutura da cela. O responsável pela manutenção deve } \\
\text { fazer a substituição, ou manutenção do piso imediatamente após a verificação } \\
\text { do problema. }\end{array}$ \\
\hline 5. & $\begin{array}{l}\text { Cela sem } \\
\text { amortecedor }\end{array}$ & $\begin{array}{l}\text { Instalar o equipamento amortecedor em todas as celas que não possuem. } \\
\text { Esta ação pode ser implantada de acordo com a disponibilidade financeira } \\
\text { da UPL. }\end{array}$ \\
\hline 6. & $\begin{array}{l}\text { Falta de iluminação } \\
\text { noturna }\end{array}$ & $\begin{array}{l}\text { Ligar todas as luzes do setor de maternidade durante a noite, para que os } \\
\text { leitões tenham visibilidades e possam dirigir-se ao escamoteador quando a } \\
\text { matriz levantar. Sugere-se que sejam instaladas lâmpadas Led, para diminuir } \\
\text { o gasto com energia elétrica. Todos os trabalhadores devem ser comunicados } \\
\text { desta ação, sendo que quem estiver na granja pode efetuá-la. Isso pode ser } \\
\text { implementado imediatamente. }\end{array}$ \\
\hline 7. & Estresse da matriz & $\begin{array}{l}\text { Fazer o mínimo de barulho possível dentro das instalações, a fim de deixar as } \\
\text { matrizes relaxadas. Deixar de usar o cachimbo (Equipamento de Contenção } \\
\text { de Suínos) durante as vacinações de rotina na UPL. Todos os trabalhadores } \\
\text { devem ser comunicados desta ação através de um aviso no mural do } \\
\text { escritório. Isso pode ser realizado imediatamente. }\end{array}$ \\
\hline 8. & $\begin{array}{l}\text { Ambiente muito } \\
\text { frio }\end{array}$ & $\begin{array}{l}\text { Fazer um estudo de custo/benefício para a possível instalação de aquecedores } \\
\text { no setor de maternidade da UPL. Caso não seja viável a instalação dos } \\
\text { aquecedores, os trabalhadores podem usar lonas plásticas para cobrir as celas } \\
\text { nos dias mais frios. Isso fará com que o calor se concentre dentro das celas, } \\
\text { mantendo os leitões aquecidos e evitando que eles fiquem embaixo da matriz } \\
\text { em busca de calor. De acordo com o médico veterinário que participou da } \\
\text { reunião de Brainstorming, essas lonas plásticas podem ser usadas nos dias } \\
\text { em que a temperatura interna da sala de maternidade for inferior a } 16^{\circ} \mathrm{C} \text {. } \\
\text { Portanto, é preciso instalar um termômetro para o controle da temperatura, } \\
\text { o qual será posicionado no centro do ambiente. Deve-se também, deixar um } \\
\text { espaço entreaberto nas celas, ou seja, não cobri-las por completo com a lona } \\
\text { plástica, para que o ambiente seja ventilado. Essa ação pode ser providenciada } \\
\text { de acordo com a disponibilidade financeira da empresa. }\end{array}$ \\
\hline
\end{tabular}




\begin{tabular}{|c|c|c|}
\hline $\mathbf{N}^{\circ}$ & $\begin{array}{c}\text { Problemas } \\
\text { identificados }\end{array}$ & Sugestões \\
\hline 9. & $\begin{array}{l}\text { Ambiente muito } \\
\text { quente }\end{array}$ & $\begin{array}{l}\text { Além do gotejamento nas matrizes, sugere-se a instalação de um ventilador } \\
\text { em cada sala de maternidade para a maior circulação do ar. Este ventilador } \\
\text { deve ser instalado de maneira que o vento não atinja as matrizes e nem os } \\
\text { leitões para evitar possíveis enfermidades. Conforme o médico veterinário } \\
\text { que participou das reuniões de Brainstorming, os equipamentos devem } \\
\text { ser acionados quando a temperatura interna das salas de maternidade } \\
\text { ultrapassar os } 28^{\circ} \mathrm{C} \text {. Podem ser usados juntamente com o gotejamento se } \\
\text { necessário. Para controlar a temperatura, será necessária a instalação de } \\
\text { um termômetro, que deve ficar no centro da sala de maternidade. Sugere- } \\
\text { se também que seja feito um estudo de viabilidade para a instalação de } \\
\text { climatizadores automatizados no setor da maternidade. Essa ação pode ser } \\
\text { implementada conforme a disponibilidade financeira da UPL. }\end{array}$ \\
\hline 10. & $\begin{array}{l}\text { Falta de funcionário } \\
\text { noturno }\end{array}$ & $\begin{array}{l}\text { Contratar um funcionário para cuidados noturnos da UPL. Este deverá } \\
\text { passar por um treinamento, com o objetivo de conhecer todos os processos } \\
\text { da granja. Pode ser contratado de acordo com as condições financeiras da } \\
\text { empresa. }\end{array}$ \\
\hline 11. & $\begin{array}{l}\text { Leitões andando } \\
\text { pela cela durante o } \\
\text { arraçoamento }\end{array}$ & $\begin{array}{l}\text { O responsável pelo setor de maternidade deve fechar todos os leitões com } \\
\text { idade menor que } 5 \text { dias dentro do escamoteador durante o arraçoamento. } \\
\text { Para isso, devem ser providenciadas tampas, de madeira, plástico, ou outro } \\
\text { material resistente. Estes leitões devem ser soltos somente depois que a } \\
\text { matriz deitar. Esta ação deverá ser repassada a todos os trabalhadores através } \\
\text { de um aviso no mural do escritório da UPL. }\end{array}$ \\
\hline 12. & $\begin{array}{l}\text { Classificação/ } \\
\text { manejo de leitões } \\
\text { entre matrizes }\end{array}$ & $\begin{array}{l}\text { Fazer o mínimo possível de classificação de leitões entre as matrizes. Quando } \\
\text { necessária a troca de leitões entre elas, escolher uma matriz com nível de } \\
\text { estresse mais baixo. Esta informação estará disponível no histórico da matriz } \\
\text { que receberá os leitões diferentes, o qual será desenvolvido na ação }{ }^{\circ} 1 \text {. Se a } \\
\text { matriz receptora não tiver histórico, ou seja, for uma primípara, por exemplo, } \\
\text { será preciso observar por alguns minutos a sua atitude. Se ela não aceitar } \\
\text { os leitões, eles devem ser retirados imediatamente e transferidos para outra } \\
\text { matriz mais calma. Essa ação pode ser executada imediatamente. }\end{array}$ \\
\hline 13. & $\begin{array}{l}\text { Falta de incentivo } \\
\text { para que os } \\
\text { leitões usem o } \\
\text { escamoteador }\end{array}$ & $\begin{array}{l}\text { Colocar uma fina camada de serragem na parte interna do escamoteador para } \\
\text { tornar o ambiente mais aconchegante. Sugere-se também, a instalação de uma } \\
\text { luz na parte interna do escamoteador, para manter o ambiente claro e atrair } \\
\text { os leitões pra dentro. A serragem e a lâmpada devem ser colocadas a partir } \\
\text { do nascimento dos leitões. Caso eles urinem ou defequem no escamoteador, } \\
\text { ele deve ser higienizado, para que os leitões possam usá-lo novamente. Esta } \\
\text { ação pode ser realizada imediatamente. }\end{array}$ \\
\hline 14. & $\begin{array}{l}\text { Portas de } \\
\text { contenção traseira } \\
\text { com tecnologia } \\
\text { ultrapassada }\end{array}$ & $\begin{array}{l}\text { Substituir todas as portas de contenção traseira das celas de maternidade que } \\
\text { são de modelo ultrapassado. Sugere-se que sejam usadas portas iguais às de } \\
\text { tecnologia moderna já existente na UPL, as quais apresentaram melhores } \\
\text { resultados durante a coleta de dados deste estudo. Esta ação pode ser } \\
\text { implementada de acordo com a disponibilidade financeira da granja. }\end{array}$ \\
\hline 15. & $\begin{array}{l}\text { Leitões com baixo } \\
\text { peso e últimos a } \\
\text { nascerem excluídos } \\
\text { do acesso aos tetos } \\
\text { nas primeiras horas } \\
\text { de vida }\end{array}$ & $\begin{array}{l}\text { O responsável por acompanhar os partos deve dar atenção especial aos } \\
\text { leitões com peso inferior a } 1 \mathrm{~kg} \text { ao nascimento e aos nascidos a partir do } 10^{\circ} \\
\text { leitão, fazendo com que eles ingiram o leite colostro nas primeiras horas de } \\
\text { vida. Para isso, estes leitões devem ser amamentados separadamente dos } \\
\text { demais por um período mínimo de } 1 \text { hora. Esta ação pode ser executada } \\
\text { imediatamente. }\end{array}$ \\
\hline
\end{tabular}

Fonte: Do autor (2018). 


\section{CONSIDERAÇÕES FINAIS}

Este artigo aplicou o MASP (Método de Análise e Solução de Problemas), com o objetivo de propor possíveis soluções ao problema de esmagamento de leitões de uma empresa do setor suinícola.

A partir de uma metodologia estruturada, foram utilizadas as ferramentas da qualidade, a fim de analisar o problema e encontrar suas causas fundamentais. Ao final do processo, foram apresentadas sugestões de melhoria que podem ser implementadas na empresa de acordo com suas necessidades e condições financeiras.

Através do levantamento de dados, identificou-se que o problema de esmagamento representa $7,99 \%$ das mortes de leitões na granja, o que gerou prejuízos estimados em $\mathrm{R} \$ 18.327,02$ num período de seis meses. Por meio da observação das características do problema, viu-se também que a maior parte destes esmagamentos ocorreu durante os sete primeiros dias de vida dos leitões, que são considerados mais fracos neste período.

Com o auxílio do Brainstorming e do Diagrama de Ishikawa constatou-se que o problema era provocado por causas relacionadas a material, máquina, método, meio ambiente e mão de obra. Assim verificou-se que as principais causas estão associadas com a falta de equipamentos adequados, treinamento dos trabalhadores e controle do plantel de matrizes da UPL.

Para concluir os objetivos deste artigo, foram sugeridas soluções de melhoria que buscam o aumento da produtividade e o alcance das metas propostas. Acredita-se que, se a empresa aderir às sugestões propostas, haverá uma redução das perdas referentes à morte de leitões por esmagamento e, consequentemente, o aumento do lucro.

Assim, entende-se que os objetivos deste trabalho foram alcançados, e que o MASP, é uma ferramenta importante e essencial na busca pelas causas dos problemas organizacionais, e, posteriormente, suas soluções.

\section{REFERÊNCIAS}

ABRAHÂO, Abrão A. F.; VIANNA, Wagner L.; CARVALHO, Luiz F. de O. e S.; MORETTI, Aníbal de S. Causas de Mortalidade de Leitões Neonatos em Sistema Intensivo de Produção de Suínos, São Paulo, Brazilian Journal of Veterinary Research and Animal Science, v. 41, n.2., p. 86-91, 2004. Disponível em: <http:/ /www.revistas. usp.br/bjvras/article/view/6261/7792> Acesso em: 14 mar. 2018.

AGUIAR, Silvio. Integração das Ferramentas da Qualidade ao PDCA e ao Programa Seis Sigma. Belo Horizonte: Editora de Desenvolvimento Gerencial, 2002. v. 1.

ALBERTIN, Marcos R.; PONTES, Heráclito L. J. Administração da Produção e Operações. Curitiba: InterSaberes, 2016. E-book. Disponível em: <www.univates.br/ biblioteca>. Acesso em: 12 set. 2017. 
ARIOLI, Edir E. Análise e Solução de Problemas: O Método da Qualidade Total com Dinâmica de Grupo. Rio de Janeiro: Qualitymark, 1998.

BARROS, Elsimar; BONAFINI, Fernanda. Ferramentas da qualidade. São Paulo: Pearson, 2015. E-Book. Disponível em: <www.univates.br/biblioteca >. Acesso em: 03 out. 2017.

BIAGIO, Luiz A. Como Administrar a Produção: + cursos online. Barueri, SP: Manole, 2015. E-book. Disponível em: <www.univates.br/biblioteca>. Acesso em: 12 set. 2017.

BOND, Maria T.; BUSSE, Angela; PUSTILNICK, Renato. Qualidade Total: O que é e como alcançar. Curitiba: Intersaberes, 2012. E-Book. Disponível em: <www.univates. br/biblioteca>. Acesso em: 07 out. 2017.

CAMPOS, Vicente F. TQC: Controle da Qualidade Total (no estilo japonês). 8. ed. Nova Lima, MG: Editora FALCONI, 2004.

CERVO, Armando L., BERVIAN, Pedro A., DA SILVA, Roberto. Metodologia

Científica. 6. ed. São Pulo: Pearson, 2007. E- Book. Disponível em <www.univates.br/ biblioteca>. Acesso em: 02 out. 2017.

CHIAVENATO, Idalberto. Gestão da produção: uma abordagem introdutória. 3. ed. Barueri, SP: Manole, 2014. E-book. Disponível em:<www.univates.br/biblioteca $>$. Acesso em: 12 set. 2017.

CRUZ, Vilma A. G. Metodologia da Pesquisa Científica. São Paulo: Pearson Pratice Hall, 2009. E-book. Disponível em: <www.univates.br/biblioteca>. Acesso em: 15 out. 2017.

CUSTODIO, Marcos F. Gestão da Qualidade e Produtividade. São Paulo: Pearson, 2015. E-Book. Disponível em: <www.univates.br/biblioteca>. Acesso em: 08 out. 2017.

FERREIRA, Adilson H. et al. Produção de suínos: Teoria e prática. 1. ed. Brasília, DF: ABCS, 2014. E-book. Disponível em: <http://www.abcs.org.br/attachments/-01_ Livro_producao_bloq.pdf>. Acesso em: 22 set. 2017.

GOZZI, Marcelo P. Gestão de Qualidade em Bens e Serviços: CQBS. São Paulo: Pearson, 2015. E-Book. Disponível em: <www.univates.br/biblioteca >. Acesso em: 07 out. 2017.

MELLO, Carlos H. P. Gestão da Qualidade. São Paulo: Pearson, 2010. E-Book. Disponível em: <www.univates.br/biblioteca>. Acesso em: 07 out. 2017.

MORAES, Marcos A. G.; BORGES, Eduardo C. B; SÁ, José A. S. Aplicação da metodologia MASP para redução das perdas na produção de cabos de ferramentas agrícolas: um estudo de caso. In: XXX ENCONTRO NACIONAL DE ENGENHARIA DE PRODUÇÃO, 2010, São Carlos, SP, 2010. Disponível em: <http:/ / www.abepro. org.br/biblioteca/enegep2010_TN_STO_114_750_15843.pdf> Acesso em: 12 set. 2017. 
MORON, Marie A. M. Concepção, desenvolvimento e validação de instrumento de coleta de dados para estudar a percepção do processo decisório e as diferenças culturais. 1998. 253 f. Dissertação (Mestrado em Administração de Empresas - Opção: Sistemas) - Universidade Federal do Rio Grande do Sul - UFRGS, Porto Alegre, 1998. Disponível em: <http:/ / www.lume.ufrgs.br/bitstream/ handle/10183/2070/000225414.pdf?sequence=1>. Acesso em: 03 out. 2017.

OLIVEIRA, S. T. Ferramentas para o aprimoramento da qualidade. 2. ed. São Paulo: Pioneira, 1996.

PÁTARO, Carolina R.; OLIVA, Diego C. Construindo a Pesquisa: métodos, técnicas e práticas em sociologia. 1. ed. Curitiba: InterSaberes, 2017. E-book. Disponível em: <www.univates.br/biblioteca >. Acesso em: 15 out. 2017.

PIRES, José G. C. Aprendizagem Organizacional Através da Metodologia de Solução de Problemas - MASP. Revista de Administração da FATEA, v. 9 n. 9, p. 84-100, ago.-dez., 2014. Disponível em: <http:/ / www.unifatea.edu.br/seer/index.php/raf/ article/view/1191/924>. Acesso em: 26 set. 2017.

RITZMAN, Larry P.; KRAJEWSKI, Lee J. Administração da Produção e Operações. São Paulo: Pearson, 2004. E-book. Disponível em: <www.univates.br/biblioteca>. Acesso em: 12 set. 2017.

SANTOS, Osmildo S.; PEREIRA, Julio C. S.; OKANO, Marcelo T. A implantação da ferramenta da qualidade MASP para melhoria contínua em uma indústria vidreira. In: IV ENCONTRO DA ENGENHARIA DO CONHECIMENTO ENIAC E IV ENCONTRO DE INICIAÇÃO CIENTÍFICA ENIAC, 2012, Guarulhos, São Paulo. Anais... Guarulhos: Revista Caleidoscópio, 2012. v. 1, n. 4. Disponível em: <https:/ / ojs.eniac.com.br/index.php/Anais/article/view/81/75>. Acesso em: 02 out. 2017.

SELEME, Robson; STADLER, Humberto. Controle da qualidade: as ferramentas essenciais. Curitiba: Intersaberes, 2012. E-Book. Disponível em: <www.univates.br/ biblioteca>. Acesso em: 03 out. 2017.

SILVA, Rosinda A.; SILVA, Olga R. Qualidade, Padronização e Certificação. Curitiba: Intersaberes, 2017. E-Book. Disponível em: <www.univates.br/biblioteca $>$. Acesso em: 07 out. 2017.

SOUZA, Jean C. P. V. B.; AMARAL, Armando L.; MORÉS, Nelson; TREMÉA, Sandro L.; MIELE, Marcelo; SANTOS FILHO, Jonas I. Sistemas de Produção 4 - Sistema de produção de leitões baseado em planejamento, gestão e padrões operacionais. Concórdia, SC: Embrapa Suínos e Aves, 2013. E-book. Disponível em: <http://www. cnpsa.embrapa.br/SP/leitoes/sp4.pdf>. Acesso em: 21 set. 2017.

ZSCHORNACK, Thiago; MATTIODA, Rosana A. CARDOSO, Rafaela da R. Aplicação da ferramenta MASP para direcionamento de ações de combate a inadimplência na companhia águas de Joinville. In: XVII SIMPÓSIO DE ENGENHARIA DE PRODUÇÃO, 2010, Bauru, São Paulo. Anais... Bauru: Gestão de Projetos e Engenharia de Produção. Disponível em: <https:/ / www.researchgate.net/profile/Rosana_ 
Mattioda3/publication/281243549_APLICACAO_DA_FERRAMENTA_MASP PARA_DIRECIONAMENTO_DE_ACOES_DE_COMBATE_A_INADIMPLENCIA_ NA_COMPANHIA_AGUAS_DE_JOINVILLE/links/55dcc65908aeb41644aecb64/ APLICACAO-DA-FERRAMENTA-MASP-PARA-DIRECIONAMENTO-DE-ACOESDE-COMBATE-A-INADIMPLENCIA-NA-COMPANHIA-AGUAS-DE-JOINVILLE. pdf>. Acesso em: 28 set. 2017. 